\title{
Sanctions policy for environmental crimes in Vietnam
}

\author{
Khanh Linh $\mathrm{Vo}^{1, *}$ \\ ${ }^{1}$ Vietnam Youth Academy, No.3, Chua Lang Street, Dong Da District, Hanoi city, 10000, Vietnam
}

\begin{abstract}
Environmental crimes in Vietnam by far is seen in a complicated trend which requires the State to regulate effective sanctions policy. Provisions of environmental crimes promulgated in Vietnam's criminal law have been amended for a number of times in order to meet the demanding requirement. It is shown that the awareness as well as the scope and method of using the sanctions to fight this kind of crime has been changed and raised. Moreover, these changes indicate that criminal policy in general and sanctions policy in particular for environmental crimes have been formed and basic factors have been identified. The paper is to figure out the development trend of the sanctions policy for environmental crimes in Vietnam throughout last time and to propose fundamental solutions to be prioritized in the policy implementation process.
\end{abstract}

\section{Introduction}

The Doi Moi reform (Renovation reform) initiated by the Communist Party of Vietnam and the Socialist Republic of Vietnam in the early 90s of the previous century have radically changed the status of the country's economy. Vietnam is now seen in the progress of actively promoting the industrialization - modernization revolution, approaching Industry 4.0, deeply and comprehensively integrating with the world. In addition to economic achievements, Vietnam has been facing many challenges in the field of environmental protection as a consequence and a negative side of the market economy. "We consistently assert the view in which economic development should be integrated with environmental protection. It definitely does not mean neither ignoring the environment issue including the living environment of the people due to economic development, investment nor sacrificing environment concern due to economic benefits" said Mr. Nguyen Xuan Phuc, Prime Minister of the Socialist Republic of Vietnam, on the marine environmental incident leak by Formosa discovered in April 2016 in Ha Tinh province, Vietnam. It is seen as the message of the Party and State of the Socialist Republic of Vietnam on environmental protection in the long-term vision.

Formosa $\mathrm{Ha}$ Tinh is reported as one of the enterprises causing the biggest marine environmental pollution in Vietnam for years, threatening massive fish deaths in four central provinces from Ha Tinh to Thua Thien - Hue, affecting people's livelihoods and causing economic consequences. The list of enterprises leaking pollution also includes: (a)

\footnotetext{
*Corresponding author: vokhanhlinh07031991@gmail.com
} 
Vinh Tan 2 Power Plant with the first large coal-fired power project of the Southern region located in Binh Thuan causing dust dispersion and incidents causing water leaking from cinder dumps into residential areas, whirlwind causing dust to disperse into the atmosphere in Binh Thuan province in the period of 2005 - 2016; (b) Vedan Vietnam discharging wastewater into Long Thanh district, Dong Nai province discovered in September 2008 which has turned Thi Vai river into a "dead river"; (c) The Hyundai Vinashin discharging about 800 thousand tons of untreated copper slag in Ninh Phuoc commune, Ninh Hoa district, Khanh Hoa province since 1999, which has polluted people's houses, trees and foodstuffs. It is found that the culprits of the worst environmental disasters in Vietnam during past 20 years are factories and enterprises with large capacity contributing a large proportion to economic development of the country.

It is noted that those above mentioned pollution disasters are just "the tip of the iceberg" in terms of current situation of environmental law violations in Vietnam. These violations are increasingly common and tend to increase in many areas, causing much damage to the environment, livelihoods, health and losing people's faith in the State. Lack of intensive and comprehensive implementation of Vietnam's environmental protection policy in recent years including the criminal policy on environmental crimes is fingered out as one of major reasons. In the past, the criminal legal system for environmental crimes in the Penal Code of 1985 and of 1999 did not provide for criminal prosecution of commercial legal entities committing offences, thus lacking legal framework for criminal sanctions of legal entities in the above mentioned environmental scandals. Administrative sanctions in which the compensation responsibility is clearly regulated, however, is consider being less than a deterrent by criminal sanctions.

One of noteworthy points of the new Penal Code of the Socialist Republic of Vietnam in 2015 (amended and supplemented in 2017) is that the criminal law policy on environmental crimes has been clarified. It is clearly found out the separate sanctions system applied for commercial legal entities committing offences, and the scope of sanctions application for individuals committing offences extended, imprisonment and fines increased (both in primary and additional punishments) as highlights among fundamental changes in the sanctions policy for environmental crimes. It, however, is worth paying attention to other aspects since the sanctions policy for environmental crimes in the broadest sense is not limited to changes in laws and regulations. Implementation of the sanctions policy on environmental crimes in Vietnam requires the full participation of the Communist Party of Vietnam, the National Assembly, the Government, law enforcement agencies and the whole people. Among the solutions proposed to implement the policy, it is difficult to consider the ones as the priorities in the short, medium and long-term visions. It is emphasized that the consideration shall be analyzed in the scientific foundation as well as the current situation of Vietnam. The paper is to answer those questions by focusing on the followings:

1. To analyze the basics of the sanctions policy for environmental crimes;

2. To analyze the development trend of regulations on sanctions for environmental crimes;

3. To identify fundamental solutions in the process of implementing the sanctions policy for environmental crimes.

These issues are studied on the basis of criminal law, policy research and socioeconomic practices in Vietnam. In the following part, the paper draws on the theory of legal policy, criminal policy, and criminal law policy to analyze the important framework of sanctions policy for environmental crimes in Vietnam. In addition, the paper is to analyze the changes of Vietnamese criminal law to assess the development trend of sanctions for environmental crimes. Based on scientific and practical basis, the paper proposes fundamental solutions to be prioritized implementing this policy. Method of policy analysis 
and comparison are respectively applied to conduct the research. Limitations and fundamental solutions of the sanctions policy for environmental crimes in Vietnam are also proposed in the paper.

\section{Research subjects and research methods}

In this part, information of the paper provided include: (a) Vietnam's studies on the theoretical framework of legal policy, criminal policy, sanctions policy for environmental crimes; (b) provisions on sanctions for environmental crimes in the Vietnam Penal Code from 1985 to the present. The research methods and its interpretation in every research subject are illustrated in the paper.

\subsection{Sanctions policy research in Vietnam}

Multidisciplinary, interdisciplinary and transdisciplinary approaches in social sciences have been developing in Vietnam in the past 20 years, which is a condition for legal science and public policy science to find common ground. [3] introduces the concept of legal policy as the basic principles and guidelines planned by the Party and the State in order to create the proper basis for the use of adjusting ability of laws, the correctness of organization and operation of state agencies and building the awareness and lifestyle in accordance with the law of the people. [28] further clarifies this concept by pointing out that legal policy is the operational strategy of the State in the field of regulatory adjustment, reflecting the benefits of society allocated in commune relations governed by law. Since then, studies on legal policy have gradually been concerned and shaped the theoretical framework: (a) The concept of legal policy and legal policy science [23]; (b) The object of legal policy [24]; (c) Principles and objectives of legal policy [25]; (d) Role and influence of legal doctrines on legal policy [26]; (e) Basics of law making policy (K.V. Vo, 2016) [22]; (f) Fundamentals of policy application; ( $\mathrm{g}$ ) Legal policy with the role of ensuring sustainable development (V.D. Nguyen, 2013) [14] in sectors of economics(V.D. Tran, V.C. Nguyen, 2013) [20], labor, employment (H.C. Nguyen, X.T. Doan, 2015) [9], culture [19], environment (D.H. Bui, 2017) [1], land (D.N. Pham, 2004) [15], law of the sea (B.D. Nguyen, 2012) [8].

Criminal policy is a type of specialized legal policy that is of interest to research in Vietnam. [4] argues that criminal policy is a part of legal policy, defining orientations and guidelines in the use of criminal law in the field of crime prevention and fighting. [16] states that criminal policy consists of four basic policies: crime prevention policy, criminal law policy, criminal procedure law policy, criminal law enforcement policy. Thus criminal law policy is an important component of criminal policy.

[6] finds that the criminal law policy defines the basic guiding principles of the state in legislative activities and the application of criminal law to ensure the stability of the criminal law system, strengthen the protection of human rights and the interests of society, contribute to the fight against the criminal situation. One of the important contents of criminal law policy is the criminalization and non-criminalization, in other words, the exclusion, narrowing or regulation towards a reduction in criminal sanctions in the process of developing criminal law if satisfying the necessary conditions. This content reflects the sanctions policy in the criminal law policy. [27] supplements this observation by arguing that the sanctions policy is not only to develop a punishment system but also to identify the directions of activities of the judicial authorities in the process of applying the punishment. The study also points out that the process of developing and implementing criminal policy includes: (a) Developing the theory of criminal policy; (b) Determining the dominant view of the Party and the State in developing national criminal policy; (c) Developing norms that articulate the point of criminal policy; (d) Determining the functions and duties of state 
agencies implementing criminal policy; (e) Organizing the application of criminal policy in practice. This process is only used for reference to formulate and implement the sanctions policy for environmental crimes.

In Vietnam, studies on environmental crimes have been carried out in recent years, but the amount of work on this topic is seen modest compared to other crimes. The majority of research approaches on this topic are empirical law analysis to comment on regulations on environmental crimes. Research on the sanctions policy for environmental crimes has not been given adequate attention, although a number of works have attempted to assess the trend of sanctions for $\backslash$ this type of crime. The sanctions policy is not merely a sanctions regulation but also includes the following elements: (a) the theoretical basis for forming a view of the sanctions policy; (b) the value of the sanctions policy; (c) sanctions-making policy; (d) sanctions application policy (implementation of sanctions policy); (e) punishment enforcement policy; (f) organizing a practical review of the enforcement of the sanctions policy. Key issues have been concluded in the case of analyzing the sanctions policy for environmental crimes.

\subsection{Sanctions for environmental crimes in Vietnamese criminal law}

Up to now, the National Assembly of the Socialist Republic of Vietnam has respectively promulgated the Penal Code in 1985 (amended and supplemented in 1989, 1991, 1992, 1997), in 1999 (amended and supplemented in 2009) and in 2015 (amended and supplemented in 2017). The provisions on environmental crimes that first appeared in the Penal Code of 1985 included only four offences which were prosecuted for offenders with sanctions applied as determinate imprisonment and not amended and supplemented during the period of validity. Table 1 provides information on the offences, the type of punishment and the imprisonment per year (by the lowest and highest), status of the offences after the amendments and supplements.

Table 1. Environmental offences in the Penal Code of 1985.

\begin{tabular}{|c|c|c|c|}
\hline Offences & \multicolumn{2}{|c|}{ Imprisonment } & \multirow{2}{*}{ Status } \\
\cline { 2 - 3 } & Lowest & Highest & Remained \\
\hline $\begin{array}{c}\text { Article 180. offences against regulations on land } \\
\text { management and protection }\end{array}$ & 0.25 & 7 & Remained \\
\hline $\begin{array}{c}\text { Article 181. offences against regulations on forest } \\
\text { management and protection }\end{array}$ & 0.25 & 10 & Remained \\
\hline $\begin{array}{c}\text { Article 195. offences against regulations on } \\
\text { environmental protection leading serious consequences }\end{array}$ & 0.25 & 5 & Remained \\
\hline $\begin{array}{c}\text { Article 216. offences against regulations on the } \\
\text { protection and use of historical, cultural and scenic } \\
\text { sites leading serious consequences }\end{array}$ & 0.25 & 3 & \\
\hline
\end{tabular}

The Penal Code of 1999 defines for the first time a separate chapter on environmental crimes, marking a step forward in the criminal legislation for this type of crime in Vietnam. The code only prosecutes criminal liability for offenders. The main sanctions applicable to environmental crimes include fines, community sentence, and imprisonment. Additional sanctions include a fine and a ban on holding certain positions or doing certain works. In the amendments and additions in 2009, the code removes two offences and added three new ones. Information on offences, fines per million VND (by the lowest and highest), imprisonment per year (by the lowest and highest), community sentence, and ban on holding certain positions or doing certain works, status of offences after amendments and supplements in 2009. 
Table 2. Environmental offences in the Penal Code of 1999.

\begin{tabular}{|c|c|c|c|c|c|}
\hline Offences & Fine & $\begin{array}{l}\text { Imprison- } \\
\text { ment }\end{array}$ & $\begin{array}{l}\text { Commu- } \\
\text { nity } \\
\text { sentence }\end{array}$ & $\begin{array}{c}\text { Ban on } \\
\text { holding } \\
\text { certain } \\
\text { positions or } \\
\text { doing certain } \\
\text { works } \\
\end{array}$ & Status \\
\hline $\begin{array}{l}\text { Article 182. Causing } \\
\text { environmental pollution }\end{array}$ & $\begin{array}{l}50- \\
500\end{array}$ & $0,5-10$ & $\checkmark$ & $\checkmark$ & $\begin{array}{c}\text { Amended } \\
\text { and } \\
\text { supplemented }\end{array}$ \\
\hline $\begin{array}{c}\text { Article 182a. Offences } \\
\text { against regulations on } \\
\text { hazardous waste } \\
\text { management }\end{array}$ & $\begin{array}{l}50- \\
500\end{array}$ & $0,5-10$ & $\checkmark$ & $\checkmark$ & Newly added \\
\hline $\begin{array}{l}\text { Article } 182 \mathrm{~b} \text {. Offences } \\
\text { against regulations on } \\
\text { prevention of environmental } \\
\text { emergencies }\end{array}$ & $\begin{array}{l}50- \\
500\end{array}$ & $0,5-10$ & $\checkmark$ & $\checkmark$ & Newly added \\
\hline $\begin{array}{l}\text { Article 183. Causing water } \\
\text { pollution }\end{array}$ & $\begin{array}{l}10- \\
100\end{array}$ & $0,5-10$ & $\checkmark$ & $\checkmark$ & Removed \\
\hline $\begin{array}{l}\text { Article 184. Causing soil } \\
\text { pollution }\end{array}$ & $\begin{array}{l}10- \\
100\end{array}$ & $0,5-10$ & $\checkmark$ & $\checkmark$ & Removed \\
\hline $\begin{array}{l}\text { Article } 185 . \text { Bringing } \\
\text { wastes into Vietnam's } \\
\text { territory }\end{array}$ & $\begin{array}{l}200- \\
1000\end{array}$ & $0,5-10$ & $\checkmark$ & $\checkmark$ & $\begin{array}{c}\text { Amended } \\
\text { and } \\
\text { supplemented }\end{array}$ \\
\hline $\begin{array}{l}\text { Article 186. Spreading } \\
\text { dangerous infectious } \\
\text { diseases in human }\end{array}$ & & $1-12$ & & $\checkmark$ & Remained \\
\hline $\begin{array}{c}\text { Article 187. Spreading } \\
\text { dangerous infectious } \\
\text { diseases in animals and } \\
\text { plants }\end{array}$ & $\begin{array}{l}10- \\
100\end{array}$ & $0,5-7$ & $\checkmark$ & $\checkmark$ & Remained \\
\hline $\begin{array}{c}\text { Article } 188 . \text { Destruction of } \\
\text { aquatic resources }\end{array}$ & $\begin{array}{l}10- \\
200\end{array}$ & $0,5-5$ & $\checkmark$ & $\checkmark$ & Remained \\
\hline $\begin{array}{c}\text { Article } 189 . \text { Forest } \\
\text { destruction }\end{array}$ & $\begin{array}{l}10- \\
100\end{array}$ & $0,5-15$ & $\checkmark$ & $\checkmark$ & Remained \\
\hline $\begin{array}{l}\text { Article 190. Offences } \\
\text { against regulations on } \\
\text { animal protection on the list } \\
\text { of endangered, precious and } \\
\text { rare species prioritized for } \\
\text { protection }\end{array}$ & $\begin{array}{l}50- \\
500\end{array}$ & $0,5-7$ & $\checkmark$ & $\checkmark$ & $\begin{array}{c}\text { Amended } \\
\text { and } \\
\text { supplemented }\end{array}$ \\
\hline $\begin{array}{c}\text { Article 191. Offences } \\
\text { against regulations on } \\
\text { management of wildlife } \\
\text { sanctuaries }\end{array}$ & $\begin{array}{l}50- \\
500\end{array}$ & $0,5-10$ & $\checkmark$ & $\checkmark$ & $\begin{array}{c}\text { Amended } \\
\text { and } \\
\text { supplemented }\end{array}$ \\
\hline $\begin{array}{l}\text { Article 191a. Importing, } \\
\text { spreading invasive species }\end{array}$ & $\begin{array}{l}50- \\
500\end{array}$ & $0,5-10$ & $\checkmark$ & $\checkmark$ & $\begin{array}{c}\text { Amended } \\
\text { and } \\
\text { supplemented }\end{array}$ \\
\hline
\end{tabular}

There are a number of new provisions on environmental offences, including criminal prosecution of commercial legal entities committing offences and a punishment system applied in the Penal Code of 2015. The sanctions imposed on environmental offenders are seen similar to the Penal Code of 1999. The sanctions imposed on commercial legal entities committing environmental offences include fines, suspension of operation, permanent 
shutdown, prohibition from operating in certain fields, ban on raising capital. Table 3 below presents offences; fines per million VND and imprisonment per year for individuals (by the lowest and highest); fines per million VND for commercial entities (by the lowest and highest); suspension of operation, permanent shutdown, prohibition from operating in certain fields; status of the offences after the latest amendment and supplement in 2017.

Table 3. Environmental offences in the Penal Code of 2015.

\begin{tabular}{|c|c|c|c|c|c|c|c|c|c|}
\hline \multirow[b]{2}{*}{ Offences } & \multicolumn{4}{|c|}{ Sanctions for individuals } & \multicolumn{4}{|c|}{ Sanctions for entity } & \multirow[b]{2}{*}{ Status } \\
\hline & Fines & $\begin{array}{c}\text { Impris } \\
\text { onmen } \\
t\end{array}$ & $\begin{array}{c}\text { Com } \\
\text { mu- } \\
\text { nity } \\
\text { sente } \\
\text { nce }\end{array}$ & \begin{tabular}{|c|} 
Ban on \\
holding \\
certain \\
positions \\
or doing \\
certain \\
works \\
\end{tabular} & Fines & $\begin{array}{c}\text { Suspe } \\
\text { nsion } \\
\text { of } \\
\text { opera } \\
\text { tion }\end{array}$ & $\begin{array}{l}\text { Perm } \\
- \\
\text { anent } \\
\text { shut- } \\
\text { down }\end{array}$ & $\begin{array}{l}\text { Prohibit } \\
\text { ion from } \\
\text { operatin } \\
\text { g in } \\
\text { certain } \\
\text { fields }\end{array}$ & \\
\hline $\begin{array}{l}\text { Article 235. Causing } \\
\text { environmental pollution }\end{array}$ & $50-3000$ & $0.25-7$ & & $\checkmark$ & $\begin{array}{l}3000- \\
20000\end{array}$ & $0.5-3$ & $\checkmark$ & $1-3$ & $\begin{array}{c}\text { Amended } \\
\text { and } \\
\text { supplemente } \\
\text { d }\end{array}$ \\
\hline $\begin{array}{l}\text { Article } 236 . \text { offences } \\
\text { against regulations on } \\
\text { hazardous waste } \\
\text { management }\end{array}$ & $50-1000$ & $0.25-10$ & $\checkmark$ & $\checkmark$ & & & & & Remained \\
\hline $\begin{array}{l}\text { Article 237. offences } \\
\text { against regulations on } \\
\text { prevention, response, and } \\
\text { relief of environmental } \\
\text { emergencies }\end{array}$ & $50-2000$ & $0.5-10$ & $\checkmark$ & $\checkmark$ & $\begin{array}{l}1000- \\
10000\end{array}$ & $1-3$ & $\checkmark$ & $1-3$ & $\begin{array}{l}\text { Amended } \\
\text { and } \\
\text { supplemente } \\
\text { d }\end{array}$ \\
\hline $\begin{array}{c}\text { Article 238. offences } \\
\text { against regulations on } \\
\text { protection of irrigation } \\
\text { works, embankments, and } \\
\text { disaster protection works; } \\
\text { offences against } \\
\text { regulations on protection } \\
\text { of river banks }\end{array}$ & $50-2000$ & $0.25-10$ & $\checkmark$ & $\checkmark$ & $\begin{array}{l}300- \\
5000\end{array}$ & $1-3$ & $\checkmark$ & $1-3$ & $\begin{array}{l}\text { Amended } \\
\text { and } \\
\text { supplemente } \\
\text { d }\end{array}$ \\
\hline $\begin{array}{l}\text { Article } 239 . \text { Bringing } \\
\text { wastes into Vietnam's } \\
\text { territory }\end{array}$ & $200-5000$ & $0.5-10$ & $\checkmark$ & $\checkmark$ & $\begin{array}{l}1000- \\
7000\end{array}$ & $1-3$ & $\checkmark$ & $1-3$ & $\begin{array}{c}\text { Amended } \\
\text { and } \\
\text { supplemente } \\
\text { d }\end{array}$ \\
\hline $\begin{array}{l}\text { Article 240. Spreading } \\
\text { dangerous infectious } \\
\text { diseases in human }\end{array}$ & $50-200$ & $1-12$ & & $\checkmark$ & & & & & Remained \\
\hline $\begin{array}{c}\text { Article } 241 . \text { Spreading } \\
\text { dangerous infectious } \\
\text { diseases in animals or } \\
\text { plants }\end{array}$ & $50-200$ & $0.5-7$ & $\checkmark$ & $\checkmark$ & & & & & Remained \\
\hline $\begin{array}{c}\text { Article } 242 . \text { Destruction of } \\
\text { aquatic resources }\end{array}$ & $50-1000$ & $0.5-10$ & $\checkmark$ & $\checkmark$ & $\begin{array}{l}300- \\
5000\end{array}$ & $0.5-3$ & & $1-3$ & \begin{tabular}{|c} 
Amended \\
and \\
supplemente \\
d \\
\end{tabular} \\
\hline $\begin{array}{l}\text { Article } 243 . \text { Forest } \\
\text { destruction }\end{array}$ & $50-500$ & $1-15$ & $\checkmark$ & $\checkmark$ & $\begin{array}{l}500- \\
7000\end{array}$ & $0.5-3$ & $\checkmark$ & $1-3$ & $\begin{array}{c}\text { Amended } \\
\text { and } \\
\text { supplemente } \\
\text { d } \\
\end{array}$ \\
\hline $\begin{array}{c}\text { Article } 244 \text {. offences } \\
\text { against regulations on } \\
\text { management and } \\
\text { protection of endangered, } \\
\text { rare animals }\end{array}$ & $500-2000$ & $1-15$ & & $\checkmark$ & $\begin{array}{l}1000- \\
15000\end{array}$ & $0,5-3$ & $\checkmark$ & $1-3$ & $\begin{array}{c}\text { Amended } \\
\text { and } \\
\text { supplemente } \\
\text { d }\end{array}$ \\
\hline $\begin{array}{c}\text { Article } 245 . \text { offences } \\
\text { against regulations on }\end{array}$ & $50-300$ & $0.5-7$ & $\checkmark$ & $\checkmark$ & $\begin{array}{l}300- \\
3000 \\
\end{array}$ & $0.5-3$ & $\checkmark$ & $1-3$ & Remained \\
\hline
\end{tabular}




\begin{tabular}{|c|c|c|c|c|c|c|c|c|c|}
\hline $\begin{array}{c}\text { management of wildlife } \\
\text { sanctuaries }\end{array}$ & & & & & & & & & \\
\hline $\begin{array}{c}\text { Article 246. Importing, } \\
\text { spreading invasive species }\end{array}$ & $100-1000$ & $1-7$ & $\checkmark$ & $\checkmark$ & $\begin{array}{c}1000- \\
5000\end{array}$ & $0.5-3$ & & $1-3$ & Remained \\
\hline
\end{tabular}

\subsection{Research Methods}

The paper uses the research methodology of public policy science to prove the basics of sanctions policy for environmental crimes. Actual law analysis method is used to analyze the most general features of Vietnam's criminal law on environmental crimes, sanctions for environmental crimes and its development trends. The comparison of legal regulations is also applied to compare and identify changes of Vietnam's criminal laws on environmental crimes (including the offences and punishment issues). On this basis, the paper summarizes and analyzes the status of sanctions for environmental crimes in Vietnam, including orientation perspective, construction policy, application policy and policy implementation review. It means the paper is to assess whether Vietnam's sanctions policy for environmental crimes has been approached appropriately, feasibly and in accordance with the actual situation; advantages achieved and limitations to be addressed. The paper, in conclusion, identifies and explains the fundamental solutions to be prioritized and how to implement those solutions, contributing to the effective implementation of the sanctions policy for environmental crimes in Vietnam.

\section{Result}

\subsection{Basic elements of the sanctions policy for environmental crimes in Vietnam}

Sanctions policy is an integral part of criminal law policy which sets the goal of fighting against the criminal situation with the mechanism of prohibition regulation of criminal law through identifying which acts are crimes in society. It shows that the basic objective of the sanctions policy for environmental crimes is to design and realize the application and enforcement of sanctions in accordance with the ability to prevent crimes violating the environment. The important question is raised: How is the sanctions policy developed and operated in order to implement this objective?

Firstly, to formulate policy and law formulation oriented by a system of points of view and ideology. In a single-party political system, these views are seen originated from the leadership orientation of the Communist Party of Vietnam. The viewpoint of the sanctions policy for environmental crimes in Vietnam is hence governed by the Communist Party's environmental protection policy.

Secondly, to ensure the sanctions designed in the law to function well in combating with environmental crimes. It demands to clearly define the sanctions policy which determines the possibility of sanctions policy from the beginning. Qualified and meaningful punishment design thus contributes to ensuring the effectiveness of the application and enforcement of sanctions.

Thirdly, to determine the direction of sanctions regulation implementation in practice to combat the environmental crimes which means the implementation process of the sanctions policy. Two issues should be concerned including: the direction of the application of the sanctions in the case and the involvement of the stakeholders in the process of applying the punishment. For the former, documents explaining and guiding the application of sanctions in criminal cases on the environment are required to provide. For the latter, it is necessary to clearly identify the agencies involved in the investigation, prosecution and adjudication 
of environmental criminal cases which are, in particularly, not only courts, procuracies but also state specialized management agencies at every level.

Fourthly, to pay attention the policy of executing criminal judgement for environmental crimes since the process of organizing the execution of sanctions is to realize the goals that the punishment aims to. The complex issues of judgment execution on environmental crimes are believed to focus on the execution of judgments against legal entities.

Fifthly, to organize the evaluation and review of the implementation of sanctions policy for environmental crimes. It is an important to assess the advantages and limitations of the sanctions policy for a specific time to be tested in practice. It also means to learn from experience and timely adjust the limitations of the future sanctions policy.

Thus, the sanctions policy for environmental crimes is not merely a development trend of sanctions regulations, but also includes policy-oriented viewpoints on construction, application, implementation and enforcement. Each of these elements is found as indispensable issue when analyzing sanctions policy, which is a basis for assessing the status and development trend of sanctions policy for environmental crimes in Vietnam. In Vietnam, the environmental protection policy in the period of accelerating industrialization and modernization has been paid special attention by the Communist Party of Vietnam. The Resolution No. 41-NQ/TW of the Ministry of Politics (2004) on environmental protection in the period of accelerating industrialization and modernization of the country clearly points out: "Environmental protection must follow the motto of focusing on the prevention and limiting negative impacts on the environment in combination with pollution treatment, remediation of degradation, environmental improvement and protection, nature conservation", "Strictly prohibiting the hunting of birds and animals on the list to be protected; preventing the use of fishing means to destroy aquatic resources; planning for development of marine conservation zones and wetland conservation areas", "Creating a public concern that condemns harshly for acts of unsanitary and environmental pollution in parallel with the application of punishment, strict sanctions". One of solutions mentioned in Resolution No. 24-NQ/TW of the Central Executive Committee (2013) on proactive response to climate change, strengthening natural resource management and environmental protection is: "Fully assessing damage caused by environmental pollution and clearly identifying responsibilities of agencies, organizations, enterprises and individuals. Focusing on thoroughly and definitely handling organizations which cause serious environmental pollution; applying strong sanctions, strictly handling and compelling establishments causing environmental pollution to comply with the requirements of environmental protection, pollution reduction and waste treatment according to law provisions." The conclusion No. 02-KL/TW of the Secretariat of the Central Committee of the Communist Party of Vietnam on the summation of 10 years of implementation of the Resolution No. 41-NQ/TW of the Ministry of Politics on the environmental protection in the period promote industrialization and modernization of the country summarizes and proposes complete solutions, including: "Clarifying the role and responsibilities of the heads of the committees and local governments to cause prolong environmental pollution", "Consolidating the organizational structure from the central to local levels in the direction of unifying and concentrating focal points; clearly defining the functions, tasks and roles of the environmental service, thoroughly eliminating the dispersion and overlap in the state management of environmental protection", "Continuing to review and finalize the legal system following the reality, to ensure the uniformity, to avoid duplication and conflict between environmental laws and other related fields". Despite not directly mentioned, some important resolutions of the Communist Party of Vietnam have implied criminal sanctions for environmental polluting acts through the prohibition and prevention of acts polluting and degrading the environment as well as indicates the attitude of condemnation by strict sanctions, completing the criminal law to handle acts of causing serious environmental 
pollution. These views are seen as the basis for the development of regulations on environmental crimes in the Penal Code of 1999 and the Penal Code of 2015, clearly showing the strict sanctions of the State for acts of harming the environment. The Resolution No. 49-NQ/TW of June 2nd, 2005 of the Ministry of Politics on the judicial reform strategy up to 2020 states one of the tasks of reforming sanctions policy is "Reducing imprisonment penalty, expanding the application of fine, community sentence for certain types of offences. Restricting the application of death penalty in the direction of only applying to a handful of particularly serious crimes". This view has shaped the policy of fine application and the design trend of sanctions for commercial entities with environmental crimes during the development of the Penal Code of 2015.

It is complicated to apply the sanctions since environmental crimes are kinds of crimes regulated with many specialized technical provisions on environmental areas. The participation and coordination between specialized agencies are thus required in the process of prosecution, investigation and adjudication of environmental criminal cases. On the other hand, it demands to consider which types and levels of sanctions to apply to environmental crimes in order to satisfy the crime prevention and environmental protection requirements.

Compared with traditional crimes, environmental offences are constituted by complex criminal acts and the consequences of crimes determined by many international documents and other fields of scientific and technical expertise. The description of criminal acts as well as the measurement of environmental consequences in practice require the involvement of specialized state management agencies, experts, scientists and complex technology application. Therefore, it is necessary to have a close relationship between agencies and organizations in the prosecution, investigation and adjudication activities in order to determine the crimes from which to have grounds for deciding sanctions. The Joint Circular No. 19 (2007) guiding the application of a number of articles of the Penal Code on crimes in the field of forest management, forest protection and forest product management promptly clarifies the coordination between the Ministry of Agriculture and Rural Development, the Ministry of Natural Resources and Environment, the Ministry of Public Security, the Ministry of Justice, the Supreme People's Court and the Supreme People's Procuracy in the process of applying criminal regulations in the field of forest management, forest protection and forest product management. The Joint Circular No. 02 (2009) providing guidance on coordination in crime prevention and environmental law violations fingers out the focal points of the specialized agencies namely the General Department of Environment (Ministry of Natural Resources and Environment) and the Department of Environmental Crime Prevention and Control (Ministry of Public Security) to participate in, prosecute, investigate and adjudicate criminal cases on the environment. These agencies have full environmental crime investigation skills, professional and scientific capacity to assess the acts and consequences of environmental damage, significantly contributing for the Court and the Procuracy to consider and decide the punishment.

Many sanctions applied to environmental crimes are designed in the direction of choosing between fines and imprisonment, community sentence for offenders, or fines and suspension of activities against legal entities. It ensures the individualization of the sanctions, the ability to use different criminal handling methods, however, the Judge, on the other hand, may sit in a state of confusion when choosing the sanctions if there is no specific guidance. It is questioning whether to give priority to using fine as economic sanctions or imprisonment, community sentence for educational value since most environmental offenders are reported to gain motivation from business and production profit. The direction of criminal handling for environmental crimes is different from other traditional ones, resulting in the careful consideration in selecting the sanctions to apply, especially for commercial legal entities committing offences. Is the tendency to expand the fines a top priority in handling environmental crimes? According to the provisions of 
Vietnam's criminal law, the amount of fines of environmental crimes against individuals and commercial legal entities is quite high, leading the concern on their ability to pay including other civil compensation expenses. In addition, internal risks for legal entities (tax obligations, relationships with creditors, workers' rights, etc.) when incurring sanctions are also necessary elements to be anticipated by the Judge and Procurator and clearly stated in the judgment otherwise the judgment enforcement agencies shall scope with a difficult position. It is worth noticing the neccessarity of the sanctions of legal entities; however, it is much appreciated to limit serious damages in the interests of creditors and employees. An orientation to apply sanctions in environmental cases is demanding, which symbolizes great significance in shaping the sanctions policy.

According to Vietnamese criminal law, criminal responsibility is applied for both individuals and legal entities in environmental crimes, requiring the different sanctions execution (judgment execution). For individuals serving sanctions, the criminal law enforcement policy must ensure human rights and rights of offenders such as physical safety, human dignity and the right to guaranteed standard and sufficient living condition, the right to health, the right to communication, the right to use time in prison [11] and the policy of community reintegration related to labor, vocational training, employment support, prejudice prevention [18]. Environmental offenders are supposed to apply these general policies in the judgment execution process. Criminal prosecution against commercial legal entities, in contrast, is found as a new issue in Vietnam while the development of policy and laws on enforcement of criminal judgments for commercial legal entities committing environmental crimes has some remaining with confused handling and unavoidable improper regulations.

According to Article 11, Law on Criminal Enforcement 2019, the Ministry of Public Security and the Ministry of Defense is in charge of enforcing criminal judgement while the criminal judgment enforcement agencies against criminal commercial entities are divided into cases: (a) civil judgment enforcement agencies in charge of fines; (b) criminal enforcement agency, provincial police in charge of remaining sanctions. It questions the issue to coordinate and supervise between specialized agencies in the field of environment, business, production and etc., in judgment execution process in requirement of this kind of unique crime. It is supposed that specialized criminal judgment-executing agencies have a firm grasp of the criminal judgment-executing profession while the business registration or operating license management agencies of enterprises may have strong operational management and supervision expertise of enterprises' activities [21]. Therefore, the coordination between criminal judgment executing management agencies, criminal judgment enforcement agencies and state management agencies is significantly necessary. When executing a certain sanctions for legal entities committing environmental crimes, it means that the judgment execution agencies will encounter complicated legal issues of the internal business such as tax obligations, responsibilities towards creditors, the rights of workers and etc., In practice, criminal judgment enforcement agencies repeatedly encounter non-cooperation from the business, so it necessarily requires the provisions on coercive judgment execution for commercial legal entities. This issue has been stipulated in the law and Decree No. 44/2020/ND-CP of the Government stipulating the enforcement of judgments against commercial legal entities on enforcement of judgments against commercial legal entities.

Two issues have been thus raised in the judgment execution policy for legal entities committing environmental crimes in Vietnam including: (a) the system of agencies involved in the judgment execution process; (b) the settlement of other legal issues arising during the judgment execution. Regarding the former, current provisions of the law on enforcement of criminal judgements, the law on enforcement of civil judgments have identified criminal execution management agencies, criminal enforcement agencies. 
However, there are no specific regulations in scope of laws and sub-law documents on identifying state management agencies in charge of coordinating with the above-mentioned agencies in the process of judgment execution, depending on specific cases. Legal entities who are environmental offenders are required to be classified into three groups as its broad scope [5]: (a) legal entities in industries and trades that do not require business conditions, administrative procedures (able to operate as long as business registration); (b) legal entities belonged to conditional business lines; (c) legal entities with certain activities required to carry out administrative procedures before performing its operation (licenses, practice certificates and equivalent documents). The criminal judgment enforcement agencies, hence, coordinate with the state management agencies corresponding to the business sector. For example, criminal judgment enforcement agencies request the Securities Commission to ban the issuance and sale of securities by legal entities to enforce the ban on raising capital. The latter is considered to be complicated since the judgement execution may affect other legal issues of the business in relation to the State, creditors and workers. It is theoretically seen as the risk that legal entities incur but it requires the judgment execution process to anticipate and take appropriate actions to ensure the rights of creditors and workers. Criminal prosecution of legal entities is a new issue, so the guidelines on the two issues mentioned above are supposed not comprehensive enough which demand more attention in completing the enforcement policy for environmental crimes.

\subsection{Development trend of sanctions for environmental crimes in Vietnam}

Table 1 provides information on environmental crimes; type and level of sanctions in the 1985 Penal Code. Environmental offences does not defined in a separate chapter of the Code but in the offences provision of economy, public order, public safety, administrative management order. Four environmental offences were stated in the 1985 Penal Code and were not amended and supplemented during the implementation of the Penal Code of 1985. Although these regulations have contributed to the attitude of condemning acts of harming the environment and raising awareness about environmental protection, remains are found [7]: (a) the law stipulates in general, wide scope makes it difficult to apply; (b) crime constituents which has not yet detailed the criminal acts that make it difficult to identify crimes; (c) acts of harm to the environment are not fully regulated; (d) not updated regularly through revisions. Despite of its awareness of the seriousness of infringement and causing environmental pollution acts, the provisions of the Penal Code of 1985 did not meet expectations as an effective tool to reverse the violation situation of environmental field. It is reported the limitation is originated from the absence of comprehensive and systematic views on criminal policy for environmental crimes, so the sanctions policy for this type of crime has not been clearly defined.

The Penal Code of 1999 has been revised these limitations. It can be seen from analysis of Table 2 that there are total eleven ten criminal offences, three new added and two removed in the amendments and supplements in 2009, bringing the total number of environmental offences to eleven. The law envisages a lot of acts that harm the environment of water, air, forests, land, and natural ecosystems. Different penalties are designed including fines, community sentence, imprisonment and ban from holding certain posts or doing certain works, and facilitating the personalization of sanctions and flexible use of sanctions to fight environmental crimes. The large fine margin is ranging from VND 10 million to VND 1 billion and applied to most offences except the spreading dangerous diseases in humans (Article 186). The imprisonment is assessed to be stricter than the previous law, ranging from 06 to 15 years. All offences are subject to community sentence except for spreading dangerous diseases in human (Article 186). Additional sanctions are regulated to apply for all offences. 
The Penal Code of 1999 clearly outlines Vietnam's criminal policy perspective on environmental crimes. Crime constituents and sanctions regulations have been designed more fully and diversely. The sanctions for environmental crimes in this law own the following characteristics: (a) a flexible and selective mechanism for deciding sanctions; (b) a fine level is high relative to the general level of fines in the law; (c) the higher imprisonment levels reflecting the condemnation attitude of acts of aggression and pollution to the environment; (d) additional sanctions to eliminate the possibility of continuous crime. During this period, the coordination mechanism between the Ministry of Agriculture and Rural Development, the Ministry of Natural Resources and Environment, the Ministry of Public Security, the Ministry of Defense, the Ministry of Justice, the Supreme People's Court and the People's Procuracy Supreme has been established, contributing to improving the quality of investigation, prosecution and adjudication of criminal cases in the field of environment. The co-operation between criminal judgment enforcement agencies and local state management agencies such as the Department of Natural Resources and Environment, and the Department of Planning and Investment has initially supported the smooth execution of criminal judgement of environmental crimes. It can be seen that the sanctions policy for environmental crimes during this period was formed as follows: (a) building a clear view of the use of sanctions to combat environmental crimes (flexible sanctions system with strict level); (b) criminal procedure provisions that have assisted the process of sanctions execution; (c) criminal justice enforcement developed contributes to favorable enforcement of environmental crimes. However, the biggest limitation of the criminal policy in this period is lack of prosecution of criminal liability for commercial legal entities, resulting in no basis for criminal handling of legal entities causing environmental pollution.

The provisions on environmental crimes in the Penal Code of 2015 are greatly revised compared to the Penal Code of 1999, including: (a) a detailed description of the offences; (b) criminal prosecution of a commercial entity committing a crime; (c) the widen scope and higher fines; (d) sanctions supplemented for commercial legal entities [2]. New noteworthy points are inherited and developed from the Penal Code of 1999 such as a more flexible and diversified mechanism for selecting sanctions, increasing additional sanctions, and aggravating tendencies. Table 3 shows there are twelve offences in the field of environment and the sanctions system applied to individuals and legal entities. The criminal prosecution of commercial legal entities committing offences is one of the important new points of the Penal Code 2015, showing that the sanctions policy for this type of crime is increasingly complete.

The sanctions applicable to environmental offenders in this law are noted with the following characteristics: (a) a higher fine of VND 50 million - VND 5 billion; (b) a wider range of imprisonment ranges from 03 months to 15 years; (c) community sentence applied to the majority of environmental crimes; (d) Additional sanctions of ban from holding certain posts, practicing certain occupations or doing certain duties applied to all environmental crimes. The biggest change in this period is that the fine is increased many times more than the previous code.

The regulations on sanctions newly applied to a commercial legal entities who are environmental offenders have the following characteristics: (a) only apply to legal entities on eight out of environmental crimes; (b) a fine ranging from VND 300 million to VND 20 billion; (c) suspension of operation ranging from 06 months to 3 years; (d) permanent shutdown applied to most offences except the destruction of aquatic resources (Article 242) and importing, spreading invasive species he import and distribution of invasive alien species (Article 246); (e) additional sanctions for prohibition from operating in certain fields and banning capital mobilization applied to all offences.

From 1985 up to now, regulations on environmental crimes have more comprehensively 
finalized, showing that Vietnam's criminal policy on crimes has been clearly clarified. The objective of the sanctions in the fight against environmental crimes has been clearly defined; the regulations on sanctions are getting more complete and diverse. It proves that the construction of sanctions for environmental crimes has been formed by a clear strategy. It is worth summarizing those following notable points of the development trend of sanctions for environmental crimes in Vietnam since 1985:

Firstly, the trend of sanctions is found becoming more and more diverse with different sanctions to choose while applying the same sanctions frame. It is clearly seen that the Penal Code of 1985 only provides imprisonment sanctions, the Penal Code of 1999 does more sanctions for individuals committing offences and initially designs options for sanctions in each sanctions frame. The Penal Code of 2015 includes sanctions for commercial legal entities committing offences and more complete designs for sanctions options. These changes facilitate the personalization of sanctions corresponding to the seriousness of each offense. On the other hand, the Judge can select different sanctions to apply, depending on the characteristics of the offender in which each sanction is calculated in terms of its feasibility and sanctions.

Secondly, the upward trend of aggravating in sanctions regulation. Imprisonment levels of the Penal Code of 1999 and 2015 have significantly increased compared to the Penal Code of 1985. In addition, fines is also increased many times for individuals and legal entities, leading the environmental criminal offenders into the criminal group with the highest fine of Vietnam's criminal law.

Thirdly, the trend of widening the scope of fines regulation. The fine was regulated to fight against environmental crimes from the Penal Code of 1999 and continuously promoted in the Penal Code of 2015 as a major and effective handling measure. This trend is said in line with the policy reform of Vietnam's criminal law set in the period of 20052020 in the orientation of Resolution No. 49 of the Ministry of Politics.

Fourthly, the trend of expanding the scope of additional sanctions regulations. Additional sanctions for environmental offences are first appeared in the Penal Code of 1999 and expanded in the Penal Code of 2015. "Ban from holding a position, practicing a profession or doing certain businesses", "prohibiting business, banning activities in certain areas" and "banning capital mobilization" are deemed necessary to prevent the possibility of continuing to conduct acts of causing environmental pollution of individuals and legal entities after the execution of the main sanctions.

It can be seen that the change of sanctions for environmental crimes is guided under strategic views, planning and specific goals of each type of sanctions when applied, the possibility of applying sanctions to achieve the objective of criminal policy for environmental crimes. It indicates that the policy of developing sanctions for environmental crimes in Vietnam in recent years has made remarkable achievements.

\subsection{Priority solution for implementing the sanctions policy for environmental crimes in Vietnam}

It is realized that the environmental crimes is not new issues in Vietnam, however, the level of criminal law improvement in this area is slower than other types of crime. The criminal policy for environmental crimes which is seen lack of breakthroughs as well as its realization regulated in laws is one of the reasons. The Penal Code of 2015 issues positive signals showing that the criminal policy for environmental crimes is reflected in the laws. Due to its unique political system characteristics, the criminal policy in general and the sanctions policy in particular are not merely changes in criminal law but also shaped by the views of the Communist Party of Vietnam, and other respects of policy application, implementation and review. Therefore, in order to have a comprehensive look of the 
sanctions policy for environmental crimes in Vietnam, it is necessary to evaluate comprehensively from the Communist Party of Vietnam system of views on this issue, as well as regulations of criminal procedure law, criminal law enforcement law and other fields. There is no perfect policy without its own limitations. The problem is addressed by identifying priority solutions corresponding to these limitations. In the research scope, the paper is to point out some limitations (issues to be discussed) in the sanctions policy for environmental crimes in Vietnam as follows:

Firstly, the viewpoint of handling law violations in the field of environment has not been adequately mentioned in the Resolutions of the Ministry of Politics, the Central Committee of the Communist Party of Vietnam. Currently, two important resolutions related to the field of environmental protection are the Resolution No. 41-NQ/TW of Ministry of Politics (2004) on environmental protection during the period of accelerating industrialization and modernization and Resolution No. 24-NQ/TW of the Central Executive Committee (2013) on proactive response to climate change, strengthening natural resource management and environmental protection. Resolution No. 41 has been summarized for 10 years of implementation in Conclusion No. 02-KL/TW of the Secretariat of the Central Committee of the Communist Party of Vietnam in 2014. The resolutions have pointed out the environmental protection solutions in which stated views on handling of environmental law violations. However, this mention is still at a modest level which has not yet been taken into a major view for a strong attitude towards the handling of violations of environmental laws, especially criminal sanctions. Meanwhile, the practice of violating environmental laws is becoming increasingly complex, which is a major cause of serious environmental pollution.

Secondly, the coordination between state management agencies and the system of judicial agencies at all levels is reported not actively effective. This inactive relationship makes it difficult for the judicial authorities to prosecute, investigate, and adjudicate, thereby affecting the effectiveness of the sanctions decision. Relationships between these agencies have not been maintained and exchanged professional knowledge regularly, most of which arise in case of incidents. Conflict in the adjudicating profession with other operations of state agencies is part of the cause of difficulties in criminal proceedings in environmental cases.

Thirdly, the application of sanctions for environmental crimes is found not to be unified. Vietnamese criminal law designs many options to apply to environmental crimes, thus resulting in the priority hierarchy of sanctions as well as assessing the effectiveness of each sanctions to apply by each Judge are not the same. On the other hand, the documents guiding the application of regulations on environmental crimes of the Council of Judges of the Supreme People's Court are not available, so the practice of applying sanctions still remains confusing.

Fourthly, the policy of criminal judgement execution against commercial legal entities committing environmental crimes faces many practical obstacles. It comes from the coordination between judicial agencies, criminal judgment enforcement agencies, criminal judgment enforcement agencies, and specialized state management agencies involved in the execution of criminal judgement. Besides, other legal issues of enterprises arising during judgment execution are also challenging issues during this process.

Solutions to implement the sanctions policy for environmental crimes in Vietnam are supposed to address the above limitations as follows:

Firstly, to study the demand to issue a Resolution of the Central Committee of the Communist Party of Vietnam on environmental policy. This resolution focuses on the following issues: (a) defining the objective of developing and completing legal policies and legal systems on environmental protection; (b) completing the criminal policy for environmental crimes, especially the sanctions policy, to show a strong and thorough 
attitude towards environmental crimes; (c) emphasizing interdisciplinary coordination solutions between judicial and state management agencies from central to local levels in the practice of criminal and environmental management and adjudication; (d) identifying criminal penalties orientation for environmental crimes; (e) directing to organization of criminal judgment execution for legal entities committing environmental crimes. This resolution is supposed to set political bases and guidelines for the comprehensive design of legal policies on environmental protection as well as clearly form the sanctions policy for environmental crimes. If this solution cannot be implemented, in the short term, it is necessary to include the above points in the Resolution of the 13th National Congress of Communist Party of Vietnam for the term of $2021-2025$.

Secondly, to issue a Joint Circular between the Ministries and the Supreme People's Court and the Supreme People's Procuracy providing for the coordination in criminal proceedings regarding environmental cases. This Circular is addressed to focus on the following issues: (a) defining the professional roles and involvement of the Ministry of Public Security, the Ministry of Defense, the Ministry of Natural Resources and Environment, the Ministry of Agriculture and Rural Development, the Ministry of Planning and Investment, the Ministry of Science and Technology, the Supreme People's Court and the Supreme People's Procuracy in process of state management and investigation on criminal cases about the environment; (b) particularly emphasizing the roles of the General Department of Environment (Ministry of Natural Resources and Environment) and the Department of Environmental Crime Prevention and Control (Ministry of Public Security) as professional bodies in areas of handling violations against environmental crimes in relation to the People's Courts and the People's Procuracies of all levels; (c) establishing a coordination mechanism, inter-sectoral reporting, regularly updating the state management of environmental protection, environmental crimes judgement, professional exchange among agencies aiming to improve the quality of the adjudication of environmental cases of the judicial system; (d) establishing a coordination mechanism between departments, people's courts, and local people's procuracies. This solution is an effective mechanism to contribute to increasing the effectiveness of judgments in general and apply penalties in particular to environmental crimes.

Thirdly, to issue a Resolution of the Council of Judges of the Supreme People's Court on guiding the application of penalties for environmental crimes. This resolution is supposed to guide the following operations: (a) perspective on the application of penalties for environmental crimes; (b) the principle of determining primary penalties in selected sanctions of environmental crimes; (c) the principle of applying additional penalties. With the characteristics of environmental crimes that do not directly infringe on human life and health, criminal penalties should be prioritized for the ability to recover environmental damage. This shows that the priority to apply fines instead of imprisonment is a reasonable trend, which is both humane and not deprived of liberty is a necessary condition for judgment executors to actively implement their responsibilities if any. Expanding the application of imprisonment instead of the deprivation or restriction of freedom is a trend pursued by many countries around the world. However, in many cases, the priority of imprisonment should be considered with the financial condition of the offender. Therefore, the Council of Judges of the Supreme People's Court is required to prepare specific grounds for the Judge to select the appropriate type of sanctions as well as its appropriate level. The grounds for choosing a fine or, suspension of operation, permanent shutdown, additional penalties are noted to be carefully guided in the resolution. The Council of Judges of the Supreme People's Court should set out the principles in selecting penalties through a set of tools to assess the financial capability of enterprises. The application of penalties, on the one hand, shows strict deterrence, on the other hand, does not advocate pushing businesses into financial depletion, as well as limiting the possibility of other legal risks when 
executing criminal judgement. It is demanding to provide the guidelines for handling legal risks of tax, financial obligations to creditors and employees in the direction of the Judge's decision on penalties and clearly writing in the judgment of business financial priorities that may occur in the execution of judgement.

Fourthly, to issue the Decree of Government on guidelines for the execution of criminal judgments against commercial legal entities. It is believed as a legal basis to determine the direction for organizing the execution of penalties for commercial legal entities committing environmental crimes. This decree should clearly establish the close relationship between the civil judgment enforcement agencies at all levels (for executing fines) and the criminal judgment enforcement agencies of the Police at all levels and the State agencies and other specialized agencies in organizing the execution of penalties. Many penalties imposed on commercial legal entities require the involvement of specialized agencies, the bank does not allow enterprise to continue borrowing capital for production and business while executing additional penalties of a ban on raising capital for example. The close relationship between these agencies also proves its professional meaning to handle the legal risks of enterprises when executing penalties such as: trade unions protecting the interests of workers, tax authorities undertaking tax obligations of enterprises. The purpose of this Decree is to address two issues: (a) determining the relationship between the authorities in the enforcement of penalties for environmental crimes; (b) determining the role of each agency in addressing other legal risks of the entity when executing the sanctions.

\section{Conclusion}

Environmental crime is the opposite of the developing economy in Vietnam, especially in the context that the criminal policy for this type of crime has not yet been comprehensively and fully formed. The current criminal law provisions on environmental crimes have gradually been finalized and improved the limitations of the previous laws. However, the implementation of these laws in reality still faces many difficulties due to the complexity of the laws and the remaining of the policy. It requires much more effort to regulate the sanctions to combat environmental crimes, so does the direction and plan to organize the execution, especially for commercial legal entities committing offences. The paper is to address the following objectives:

Firstly, to identify the key elements of the sanctions policy for environmental crimes including the leadership view of the ruling Party, the policy of sanctions - making, applying and enforcing. The main purpose is addressed to provide politicians, scientists, policy makers and state officers who are in charge in investigating, prosecuting, adjudicating and enforcing judgments against environmental crimes with full understanding in developing and enforcing sanctions policy for environmental crimes in Vietnam.

Secondly, to analyze the development trend of criminal policy and sanctions policy for environmental crimes in Vietnam in recent years, its achievements and remaining limitations. Providing readers with an overview of the formation and development of regulations of crimes and sanctions for environmental crimes in Vietnam from 1985 to the present is supposed to be one of key objectives. The paper results show that the criminal policy for environmental crimes in Vietnam has made breakthroughs in legislative thinking and techniques, especially those in the sanctions policy.

Finally, to prioritize the solutions to overcome the immediate limitations of the sanctions policy for environmental crimes in Vietnam. It is noted solutions proposed from researcher's personal perspective are resulted in-depth analysis of limitations. In details, those solutions aim to complete the sanctions policy, towards strengthening the criminal policy for environmental crimes, contributing to the effective implementation of environmental protection policy, ensuring sustainable development in Vietnam today and in 
the long-term vision.

\section{References}

1. D.H. Bui, State and Law Review 7, 60-66 (2017)

2. N.H. Bui, V.K.D. Nguyen, Journal of Procuracy Science 1, 18-22 (2018)

3. T.U. Dao, Vietnamese Criminal Law (Social sciences Publishing House, Hanoi, 2000)

4. T.M. Dinh, Journal of Human Resources of Social Sciences 1(5), 146-156 (2019)

5. V.C. Le, Basic issues in criminal law science (General section) (VNU Publishing House, 2005)

6. N.D. Ngo, Environmental crimes under Vietnam's criminal law and judicial practice in Hanoi city, Master's thesis (Hanoi, 2014)

7. B.D. Nguyen, Journal of Law 8, 68-82 (2012)

8. H.C. Nguyen, X.T. Doan, Journal of Law 2, 20-29 (2015)

9. H.H. Nguyen, Environmental crimes in Vietnam: Situation, causes and preventive measures Doctor of dissertation in law (Hanoi, 2019)

10. K.H. Nguyen, Journal of Human Resources of Social Sciences 1(5), 50-59 (2019)

11. N.H. Nguyen, Scientific commentary on the Penal Code of 2015 (amended and supplemented in 2017) (Publishing House of Justice, 2018)

12. T.C. Nguyen, Theoretical and practical issues about environmental crimes under Vietnam's criminal law Master's thesis (Hanoi, 2010)

13. V.D. Nguyen, Journal of Law 3, 10-16 (2013)

14. D.N. Pham, Legislative Research Review 6, 26-29 (2004)

15. V.L. Pham, Criminal policy in the Doi Moi in Vietnam (Publishing House of Justice, 2007)

16. T.T. Phung, Offences on causing environmental pollution in Vietnam's criminal law Master's thesis (Hanoi, 2014)

17. H.T. Tran, Journal of Human Resources of Social Sciences, Legal policy on community reintegration 1(5), 60-75 (2019)

18. T.D. Tran, Journal of Legislative Research 23, 58-69 (2015)

19. V.D. Tran, V.C. Nguyen, State and Law Review 12, 25-34 (2013)

20. H.C. Vo, Journal of Human Resources of Social Sciences 1(5), 131-138 (2019)

21. K.V. Vo, Journal of Human Resources of Social Sciences 7, 3-11 (2016)

22. K.V. Vo, Journal of Human Resources of Social Sciences 2, 3-11 (2015)

23. K.V. Vo, Journal of Human Resources of Social Sciences 10, 3-16 (2015)

24. K.V. Vo, Journal of Human Resources of Social Sciences 12, 3-18 (2015)

25. K.V. Vo, Journal of Human Resources of Social Sciences 6, 3-16 (2016)

26. K.V. Vo, Legal Policy (Social sciences Publishing House, 2020)

27. K.V. Vo, Sociology of Law: Basic issues (Post-graduate curriculum) (Social sciences Publishing House, 2012) 